\title{
The effect of airline lounge services on the selection of airline
}

\author{
Samet Can Curkan*, Esin Özkan
}

\section{ABSTRACT}

\author{
Keywords: \\ Lounges, \\ Service quality, \\ Lounges, \\ Service quality.
}

The services provided at lounges, designed in line with various needs with the purpose of enabling the passengers to make use of the waiting time at the airports, affect the selection of airlines. In this study, the effect of image and accessibility, atmosphere, food E beverage and opportunities (activity) dimension belonging to lounge scale on the selection of airline is analyzed. The utmost limitedness of the study is conducting the questionnaires on passengers using Izmir Adnan Menderes airport domestic flights lounge. The questionnaires and comparative analyses to be conducted at different airports will add another dimension to the study. "Image and accessibility of the lounges have a positive significant effect on airline selection" is the only accepted hypotheses of the study. The most important result obtained from the study is that image and accessibility dimension among the lounge services has a significant and positive effect in the selection of the airline. In accordance with the results of the study, it is suggested to airlines to position the lounges within the airport to a place that passengers can easily reach, share the feedbacks of the passengers using the lounges via social media channels, promote the passengers to recommend the lounges and finally follow correct marketing exercises and sales techniques.
Submitted: 02.08.2020

Accepted: 28.12 .2020

Doi: https://doi.org/10.31822/jomat.789635

\section{Introduction}

Airline industries contribute to the economies of the countries greatly (Uz \& Canarslan, 2019). Air transportation can be as freight (such as cargo, post) and passenger transportation. Passengers can benefit from various services at the airports. Lounges are the primary ones among them. People want to use their time more efficiently by waiting their departure times at customized lounges instead of common areas. Especially the class travelling for business prefer lounges more often. Passengers use lounges for various reasons such as organizing their works, resting, meeting their eating and drinking needs while waiting for their departure times. Lounges provide different services as well as meeting the basic needs of the passengers. Interactive options (internet, multimedia etc.) are the leading ones among these services. People who travel frequently prefer lounges with the purpose of feeling comfortable, having a good time and resting during the waiting period for their departure times or during the transfer period while going from one region to another. Lounges can be managed either by airport ground handling companies or the airlines. The services provided at lounges belonging to airlines can affect the airline selection of the consumers. The problem statement of this study is "What is the effect of the variables belonging to the lounges on airline selection?"

\section{Conceptual Framework}

In management science, especially in total quality management studies, quality is defined as the level of meeting the expectations of people who are provided with goods or services (Yamak, 1998). It is seen that customer and product-oriented statements adopting holistic approach are used while defining quality (Halis, 2010). European Organization for Quality and American Society for Quality identify quality as the total of the features presenting the capability of a product or a service to meet a certain need (Clausing, 1990: as cited in Halis, 2010).

Before referring to the concept of service quality, it will be to the point to make the definition of the service. Service is defined in various ways in accordance with the approaches. Service is an activity or a benefit provided by one side for another that basically cannot be touched and

\begin{tabular}{cl}
\hline${ }^{*}$ Corresponding Author & \multicolumn{1}{c}{ Research Paper } \\
\hline Samet Can Curkan: & $\begin{array}{l}\text { PhD. Res. Asst., Ege University, Çeşme Faculty of Tourism, İzmir / Turkey, Email: samet.can.curkan@ ege.edu.tr, Orcid } \\
\text { Id: 0000-0002-7245-4103 iD }\end{array}$ \\
\hline Esin Özkan: & $\begin{array}{l}\text { Prof. Dr., Aksaray University, Faculty of Tourism, Aksaray / Turkey, Email: esinozkan@ @ aksaray.edu.tr, Orcid Id: O000- } \\
\text { O002-3609-9757 iD }\end{array}$
\end{tabular}


cannot result in the possession of anything (Kotler, 1997). Service is provided as the combination of product and service in different ratios instead of providing the customer only either with product or service (Okumuş \& Asil, 2007).

Many authors created different definitions for service (Solomon et al, 1985). With regard to these definitions, dimension developed for service and qualities of service can be listed as follows (Özer \& Özdemir, 2007):

- Providing benefit for both sides and meeting the demands,

- Being based on knowledge and skill,

- Hard to separate goods and services,

- Emerging as a result of actions, processes and interactions,

- Consumed immediately and the outputs are intangible,

- Production and consumption happen at the same time,

- Customers are included in the production process,

- Evaluation of service quality is subjective.

Most of the definitions regarding the service quality, on the other hand, focus on expectations before service and the evaluation of the perceptions for the performance after provided service (Tütüncü, 2001). It is getting harder to provide and evaluate the service quality depending on the qualities explained above. Within this scope, it will be beneficial to identify the factors affecting the service quality in the first place. In literature, the factors affecting the service quality are listed as accessibility, communication, capability, kindness, credibility, reliability, responsiveness, reliance, trying to understand customer (Kotler et al., 1999, as cited in Küçükaltan, 2007:63).

There are two main basic perspective about service quality scale. One is the American (Parasurman et al.'s), the other is European (Grönroos's) perspective (Kang and James, 2004). Service quality is a determinant that has a direct effect on the behavioral intentions of the passengers (Park, Robertson \& Wu, 2005). Airline service has a quite complicated structure. Services provided by airlines can be listed as cabin service, seat reservation, ground services, food service, flight operation, lounges etc. A passenger's getting any one of these airline service components missing or problematic affects the airline selection negatively (Archana \& Subha, 2012). The quality of the provided service plays an important role in the company selection of the consumer (passenger) in airline services just like in all sectors (Munusamy, Chelliah \& Pandian, 2011). There are many studies discussing the effect of airline service quality on customer satisfaction and loyalty to the company (Saha \& Theingi, 2009). A study researching the effect of the service provided at lounges on customer preference isn't encountered. And this fact presents the authenticity of the study.

\section{Method}

In this part of the study, information regarding the purpose of the study and the problem, universe and sample group, information gathering process and analysis methods will be given. The biggest determinant in the creation of this study is the motive to identify the effect of airline lounge services on airline selection. With reference to this problem statement, the scale used by Han, Ham, Yang and Baek (2012) with the purpose of measuring consumers' perception on airline lounge, was applied with dispensation on passengers using İzmir Adnan Menderes Airport domestic lines lounges between March - June of 2019. The passengers who got lounge service at the airports constitute the universe of the study. The sample group of the study is the passengers who used İzmir Adnan Menderes Airport lounge. 320 questionnaires were collected by face-to-face interview method. Invalid 21 questionnaires were not included in the analysis and the forms filled by 299 passengers were considered valid.

Frequency analysis was made in order to identify demographic features of the participants while descriptive analysis was made to analyze the habits of the participants for lounge usage. Exploratory and confirmatory factor analyses were applied to the scales used in the study. SPSS and AMOS software programs were used in the application of the analyses. The hypotheses created in parallel with the purpose of the study were tested with multivariate regression analysis.

Table 1: Hypotheses of the Study

\begin{tabular}{|l|l|}
\hline No & \\
\hline Hypothesis 1 & Image and accessibility of the lounges have a positive significant effect on airline selection. \\
\hline Hypothesis 2 & The atmosphere of the lounges has a positive significant effect on airline selection. \\
\hline Hypothesis 3 & Food \& beverage opportunities in lounges have a positive significant effect on airline selection. \\
\hline Hypothesis 4 & The opportunities belonging to the lounges have a positive significant effect on airline selection. \\
\hline
\end{tabular}




\section{Findings}

Demographic features of the participants

The participants are mainly $(65,2 \%)$ males. When the age rage is analyzed, it is seen that $31-39$ age range is predominant $(39,7 \%)$. Half of the voluntary participants have bachelor's degree. When the sample is analyzed in accordance with group professions, it is determined that selfemployed (18\%) and employers (14\%) are predominant.

Table 2: Demographic features of the sample group

\begin{tabular}{|c|c|c|c|}
\hline & & Frequency & $\%$ \\
\hline \multirow[t]{2}{*}{ Gender } & Male & 195 & 65.2 \\
\hline & Female & 104 & 34.8 \\
\hline \multirow[t]{5}{*}{ Age } & 30 and below & 62 & 20.7 \\
\hline & $31-39$ & 119 & 39.7 \\
\hline & $40-49$ & 72 & 24.0 \\
\hline & $50-59$ & 37 & 12.3 \\
\hline & 60 and over & 6 & 2.0 \\
\hline \multirow[t]{5}{*}{ Education } & $\begin{array}{l}\text { Secondary school and } \\
\text { equivalents }\end{array}$ & 1 & 0.3 \\
\hline & $\begin{array}{l}\text { High school and } \\
\text { equivalents }\end{array}$ & 31 & 10.5 \\
\hline & Associate degree & 50 & 16.9 \\
\hline & Bachelor's degree & 148 & 50.0 \\
\hline & Postgraduate & 66 & 22.0 \\
\hline \multirow{9}{*}{ Profession } & Worker & 25 & 8.3 \\
\hline & Officer & 25 & 8.3 \\
\hline & Self-employed & 54 & 18.0 \\
\hline & Retired & 12 & 4.0 \\
\hline & Student & 9 & 3.0 \\
\hline & Educator & 31 & 10.3 \\
\hline & Employer & 42 & 14.0 \\
\hline & Unemployed & 12 & 4.0 \\
\hline & Other & 84 & 28.0 \\
\hline \multirow[t]{3}{*}{$\begin{array}{l}\begin{array}{l}\text { Income } \\
\text { (monthly) }\end{array} \\
\end{array}$} & $2001-4500 \mathrm{TL}$ & 6 & 2.0 \\
\hline & $4501-7500 \mathrm{TL}$ & 65 & 21.7 \\
\hline & $7501 \mathrm{TL}$ and above & 189 & 63.0 \\
\hline
\end{tabular}

Source: Created by the author

\section{Information about the participants' flights and airline}

\section{lounge usage}

In the study conducted with the purpose of measuring the effect of perceived service quality of airline lounges on satisfaction and airline selection, the questions were addressed to the passengers using lounges in İzmir Adnan Menderes airport. When the participants' answers regarding flights and lounge usage are analyzed, it is seen that sample group mainly travel in economy class $(84,5 \%)$. Flights of the participants mostly result from holiday $(45,9 \%)$ and business $(29,3 \%)$ purposes. When travel frequency of the passengers who use lounge service is analyzed, it is seen that $61,9 \%$ of the participants flew 11 times or more in 2019. Within the same year, the frequency of lounge usage of the passengers is mainly $(43,3 \%)$ 11 or more. The majority of the participants $(59,2 \%)$ stated that they left lounges $30-60$ minutes before departure time. When the general time period spent in lounges was asked, $57,9 \%$ answered as $30-60$ minutes while $32,1 \%$ answered as $1-2$ hours. $66,2 \%$ of the passengers prefer to use the lounges along with a close person.

Lounge accompany
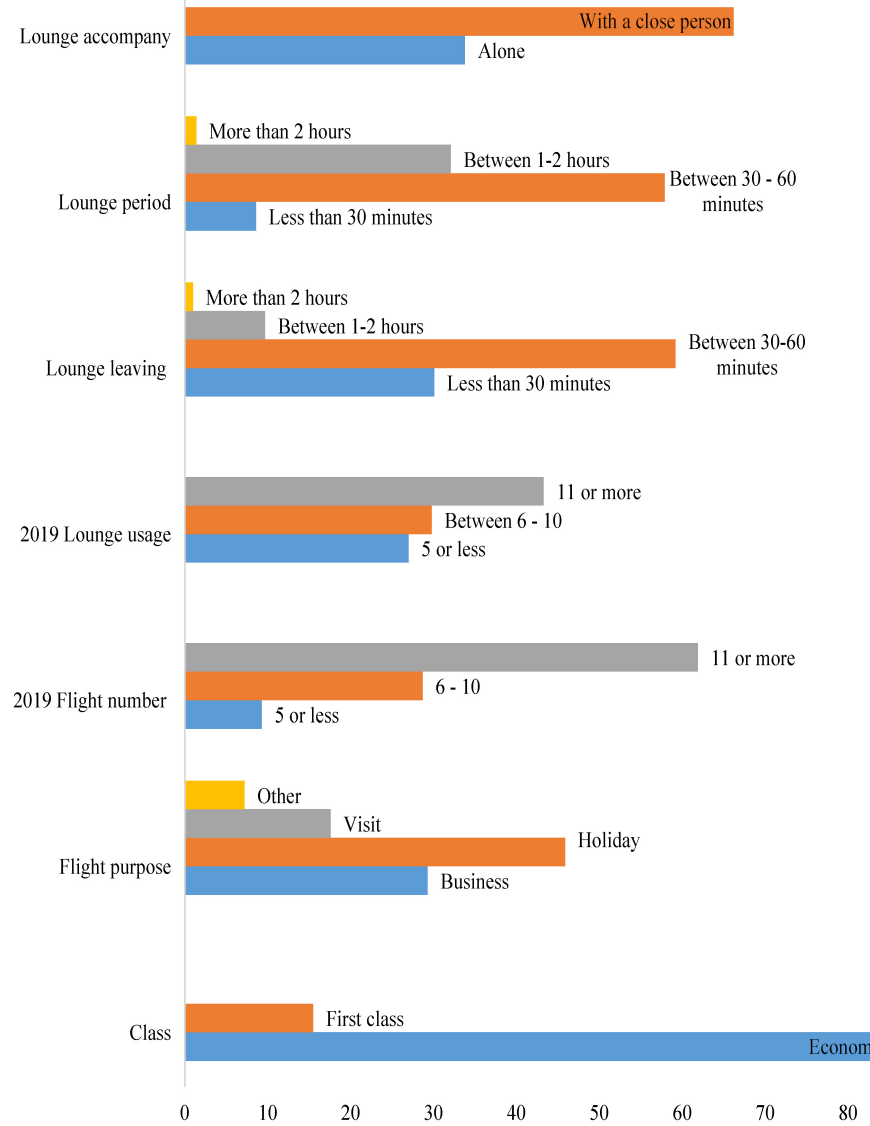

Figure 1: Participants' opinions regarding flights and lounges Source: Created by the author

Reliability and validity tests are made on two different scales existing in the questionnaire formed in compliance with the purpose of the study. One of the scales used in the study is aimed at measuring passengers' opinions regarding airline lounge service quality. Second scale used in the study is created with the intention of identifying to what extent the passengers are satisfied with the lounge services of İzmir Adnan Menderes Airport.

Average and standard deviation values of the variables belonging to the scale created with the purpose of measuring the passengers' perceptions on service quality of lounges and factor analysis results are shown in Table 3. 
Table 3: Airline lounges service quality scale

\begin{tabular}{|c|c|c|c|c|c|}
\hline \multirow[t]{2}{*}{ Variables } & \multirow[t]{2}{*}{ M+SD } & \multicolumn{4}{|c|}{ Factors } \\
\hline & & $\begin{array}{c}\text { Image and } \\
\text { Accessibility }\end{array}$ & Atmosphere & Food \& Beverage & Opportunities \\
\hline Experiencing the lounge before & $4.02+0.86$ & .848 & & & \\
\hline $\begin{array}{l}\text { Lounge's being praised and recommended } \\
\text { by others }\end{array}$ & $3.85+1.06$ & .783 & & & \\
\hline Favorable location & $4.08+0.87$ & .770 & & & \\
\hline $\begin{array}{l}\text { Impression gained by marketing and sales } \\
\text { techniques }\end{array}$ & $3.63+1.04$ & .562 & & & \\
\hline Interior design of good quality & $4.13+0.91$ & & -.880 & & \\
\hline Cozy and comfortable environment & $4.32+0.82$ & & -.848 & & \\
\hline Candid and kind service & $4.24+0.85$ & & -.756 & & \\
\hline Wide and nice area & $4.16+0.88$ & & -.669 & & \\
\hline Snacks provided in different kinds & $4.06+0.98$ & & & .827 & \\
\hline Light meal provision & $3.98+0.96$ & & & .800 & \\
\hline Various kinds of beverage provision & $4.12+0.95$ & & & .753 & \\
\hline Quality menu & $4.09+0.96$ & & & .715 & \\
\hline Free of charge phone usage opportunity & $3.53+1.22$ & & & & .846 \\
\hline $\begin{array}{l}\text { Availability of television programs and } \\
\text { movies }\end{array}$ & $3.56+1.16$ & & & & .805 \\
\hline $\begin{array}{l}\text { Diversity of printed publication } \\
\text { (newspaper, magazine etc.) }\end{array}$ & $3.76+1.06$ & & & & .756 \\
\hline Usage of shower cabins & $3.47+1.21$ & & & & .707 \\
\hline Eigenvalue & & 1.933 & 1.063 & 5.683 & 2.308 \\
\hline Variance extracted $(\%)$ & & 12.081 & 6.642 & 35.517 & 14.425 \\
\hline Cronbach's alpha (CR) & 0.870 & 0.833 & 0.869 & 0.857 & 0.861 \\
\hline $\begin{array}{l}\text { Average variance extracted } \\
\text { (AVE) }\end{array}$ & & 0.560 & 0.628 & 0.600 & 0.608 \\
\hline $\mathrm{M}+\mathrm{SD}$ & & $3.89+0.75$ & $4.21+0.72$ & $4.06+0.82$ & $3.58+0.92$ \\
\hline
\end{tabular}

Table 3 shows the frequency analysis (average and standard deviation) exploratory factor analysis and reliability results for the variables of airline lounges service quality scale. Exploratory factor analysis (EFA) is used for revealing the factor structures (Suhr, 2006) of the scales either created new or translated from one language into another (Reyment \& Jöreskog, 1996). The SERVQUAL scale, developed by Fick and Ritchie (1991) and used in many different studies in order to measure the quality of services provided at tourism establishments such as airline, hotel, restaurant and ski centers, is used in the study. The SERVQUAL scale translated into Turkish with the intention of measuring the service quality of airline lounges provided to the sample group of the study is composed of 17 statements. As a result of the first exploratory factor analysis, it is determined that the factor load of the statement (availability of internet and computers) that was expected to be loaded under opportunities (activity) dimension is low (,551). When the literature is reviewed, different explanations are made regarding the factor load values of the items. Kline (1994) define the load value between $0.30-0.59$ as medium-level and load value above 0.60 as high level. As a result of the factor analysis, it is determined that the item having ,551 factor load is intertwined with the opportunities and food\&beverage dimensions. It is observed that related item decreases the reliability level of the dimension. Lastly, it is seen before removing the item that the model disarrays the conformity in exploratory factor analysis (EFA) table. Therefore, related item is excluded from the scale.

Airline lounges service quality scale, whose final state is composed of 16 items, is applied the reliability analysis. According to the test result applied to the whole scale, the scale is concluded to be reliable $(\mathrm{CR}=0,870)$. Cronbach Alpha and AVE tests are made in order to identify the reliability levels of four dimensions existing in the scale. It is stated that all of the dimensions' reliability levels are in the desired range.

In pursuit of the analyses of the scale used to measure airline lounges service quality, the scale developed for identifying İzmir Adnan Menderes Airport lounge services is tested. Average values, standard deviations, factor analysis results and reliability analysis of the statements belonging to the scale developed for identifying İzmir Adnan Menderes Airport lounge services are given in Table 4. 
Journal of multidisciplinary academic tourism 2021, 6 (1): 17-26

Table 4: İzmir Adnan Menderes Airport lounge services scale

\begin{tabular}{|c|c|c|c|c|c|}
\hline \multirow[t]{2}{*}{ Variables } & \multirow[t]{2}{*}{ M+SD } & \multicolumn{4}{|c|}{ Factors } \\
\hline & & $\begin{array}{c}\text { Atmospher } \\
\text { e }\end{array}$ & $\begin{array}{l}\text { Food \& Beverage } \\
\text { Variety }\end{array}$ & $\begin{array}{c}\text { Staff } \\
\text { Competence }\end{array}$ & Opportunities \\
\hline Has a broad and nice ambience & $4.20+0.75$ & .888 & & & \\
\hline Is cozy and comfortable & $4.28+0.62$ & .887 & & & \\
\hline Is hygienic and clean & $4.33+0.64$ & .730 & & & \\
\hline Has an interior design of good quality & $4.30+0.69$ & .698 & & & \\
\hline Has adequate variety of beverages & $4.20+0.81$ & & -.719 & & \\
\hline Snack menu's variety is on adequate level & $4.08+0.98$ & & -.716 & & \\
\hline Snack menu is of good quality & $4.13+0.83$ & & -.660 & & \\
\hline $\begin{array}{l}\text { Employees are sensitive about the } \\
\text { requirements of the customers }\end{array}$ & $4.33+0.67$ & & & .876 & \\
\hline Employees are kind and respectful & $4.43+0.67$ & & & .838 & \\
\hline Service is on time and fast & $4.33+0.79$ & & & .741 & \\
\hline Employees are clean and well-dressed & $4.49+0.66$ & & & .711 & \\
\hline $\begin{array}{l}\text { Employees are well-educated and } \\
\text { experienced }\end{array}$ & $4.34+0.73$ & & & .628 & \\
\hline $\begin{array}{l}\text { Printed publications' (newspaper, magazine } \\
\text { etc.) variety is adequate }\end{array}$ & $4.25+0.85$ & & & & .830 \\
\hline Internet and computer are available & $4.35+0.78$ & & & & .775 \\
\hline Television and various movies are available & $4.04+0.99$ & & & & .691 \\
\hline Eigenvalue & & 5.842 & 1.086 & 1.420 & 2.052 \\
\hline Variance extracted (\%) & & 38.945 & 7.241 & 9.469 & 13.681 \\
\hline Cronbach's alpha (CR) & 0.882 & 0.879 & 0.740 & 0.859 & 0.810 \\
\hline Average variance extracted (AVE) & & 0.648 & 0.488 & 0.672 & 0.589 \\
\hline $\mathrm{M}+\mathrm{SD}$ & & $4.27+0.56$ & $4.14+0.76$ & $4.38+0.57$ & $4.21+0.69$ \\
\hline
\end{tabular}

Results of average, standard deviation, factor analysis and reliability tests applied on İzmir Adnan Menderes Airport lounge services scale are seen in Table 4. In the first exploratory factor analysis, item 17 (availability of shower cabins) and item 13 (special requests are met appropriately) are removed from the scale respectively. It is determined that the factor loads of the related items are low. Merely low factor load isn't an enough reason to remove an item from the scale. If the factor load of the item is on acceptable level (if not lower than 0,30), it is required to analyze the item in terms of the ratio it is loaded on the other items and its effect on reliability (Osborne and Fitzpatrick, 2012). Two items (item 17 and item 13) with low factor load are removed from the scale respectively and analyzed by means of different rotation techniques. However, it is ascertained that both items are not compatible with the scale and decrease the reliability levels of the affiliated dimensions. Thus, both items are removed from the scale and the final state of the scale is composed of 15 items.

In accordance with the final exploratory factor analysis result, 15-item scale is assembled under four dimensions. The first dimension comes up as "atmosphere" and is composed of four items; the second dimension is a three-item "food\&beverage" dimension; the third dimension is a six-item "staff competence" dimension and the fourth dimension is the "opportunities" (activities) dimension and is composed of four items. KMO value of the factor $(0,863)$ is above the desired level. Moreover, the result of Barlett's test $\mathrm{x} 2$ is 2206,247 ( $\mathrm{df}=105$, sig $=0.000)$. Won and Cheong (2008) emphasize that the factor loads must be greater than 0.5. As a result of the factor analysis it is ascertained that the factor loads of all of the items are greater than 0.5. Also, general reliability analysis is on the desired level $(0,882)$. When the reliability analysis results on the basis of dimensions are analyzed, it is seen that only food\&beverage dimension's average variance extracted (AVE) level is slightly below the desired level, yet it is on the acceptable level $(0,488)$.

As a result of the convergent and divergent validity analyses, the answers given to the statements by the passengers are analyzed with the purpose of evaluating İzmir Adnan Menderes Airport lounge services. In line with the answers to the statements, the statements that passengers mostly agree are respectively item 12 "employees are clean and well-dressed", item 9 "employees are kind and respectful" and item 8 "employees are welleducated and experienced." It is seen that all of the statements passengers most frequently and highly agree with are under staff competence dimension. This result shows that passengers find the service provided at İzmir Adnan Menderes Airport domestic lines lounge by the employees quite 
satisfactory. When the answers given to the 15item scale developed with the intention of service evaluation is assessed generally, it is seen that passengers are content with all of the services provided. Average values of the statements show that lowest statement is 4,04 and highest statement is 4,49 . It is observed that average values of the statements are quite high and their standard deviation is low. This result demonstrates the fact that passengers are satisfied with İzmir Adnan Menderes Airport domestic lines lounge services in general.

After frequency, reliability, validity and fact analyses were applied on both scales, confirmatory factor analysis (CFA) was applied to airline lounge service quality scale. Confirmatory factor analysis is made to test a previously used scale before applying it to a study (Yaşlıoğlu, 2017). While confirmatory factor analysis is being applied to a scale, some outputs are needed to be obtained (Bakırtaş, 2010). Also, fit indices table (parameters) used to analyze the results enable the model to be tested holistically (Byrne, 2010). The indices that are used with the purpose of testing the goodness of fit values of a model or a scale and gained acceptance in literature are SRMR x2, AGFI, GFI, RMSEA, NFI, TLI and CFI.

Figure 2 shows final confirmatory factor analysis results applied to airline lounge service quality scale. Table 5 shows the fit indices that gained acceptance in literature and their acceptance ranges (Hooper, Coughan and Mullen, 2008).

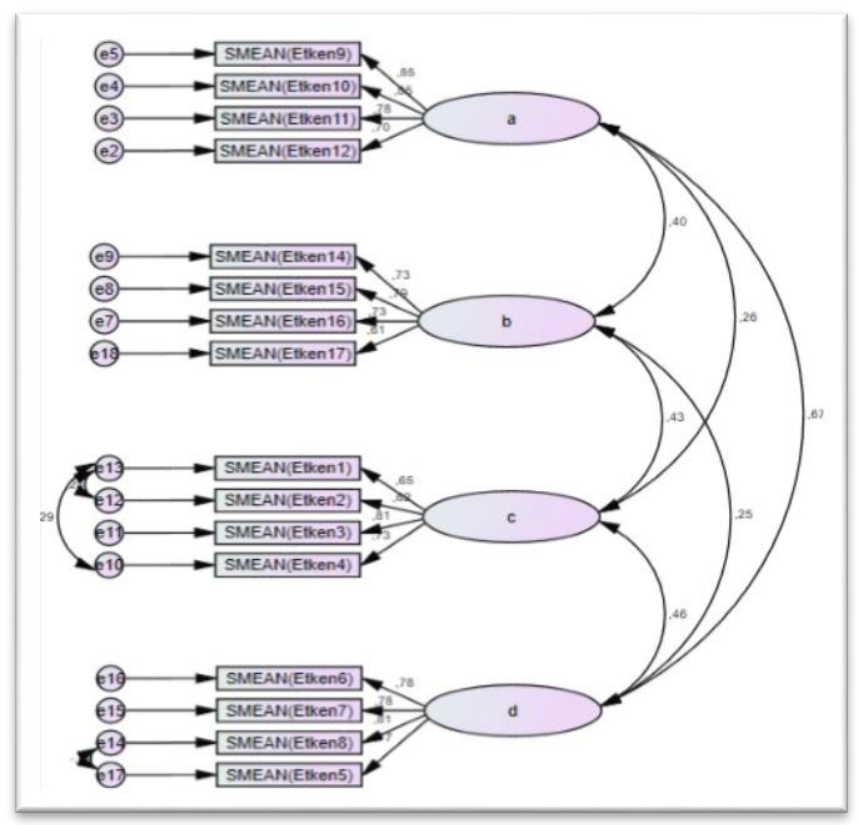

Figure 2: Final confirmatory factor analysis of airline lounge Source: Created by the author
Figure 2 belongs to final confirmatory factor analysis made on lounge service quality scale. Following the exploratory factor analysis, it is observed that item 13 (availability of internet and computers) has extreme values. Confirmatory factor analysis results are also evaluated before removing the item from the scale. It is determined that relevant item has extreme values as a result of CFA and disrupts the model. Confirmatory factor analysis is repeated after removing the same item from the scale. As a consequence of the second confirmatory factor analysis belonging to lounge service quality scale took its final form.

Table 5: Commonly used fit indices and acceptance ranges

\begin{tabular}{|l|l|l|l|l|l|l|}
\hline $\begin{array}{l}\text { Sample } \\
\text { Size }\end{array}$ & \multicolumn{2}{|l|}{$\mathbf{N}<\mathbf{2 5 0}$} & \multicolumn{2}{l|}{$\mathbf{N}>\mathbf{2 5 0}$} \\
\hline $\begin{array}{l}\text { Variable } \\
\text { number }\end{array}$ & $\mathrm{m} \leq 12$ & $\begin{array}{l}12< \\
\mathrm{m}<30\end{array}$ & $\mathrm{~m} \geq 30$ & $\mathrm{~m} \leq 12$ & $\begin{array}{l}12< \\
\mathrm{m}<30\end{array}$ & $\mathrm{~m} \geq 30$ \\
\hline CMIN/df & & $\chi 2 / \mathrm{df}<2.5$ & & & $\chi 2 / \mathrm{df}<5$ & \\
\hline GFI & $>0.95$ & $>0.90$ & $>0.90$ & $>0.90$ & $>0.90$ & $>0.80$ \\
\hline AGFI & $>0.95$ & $>0.90$ & $>0.90$ & $>0.90$ & $>0.90$ & $>0.80$ \\
\hline CFI & $>0.97$ & $>0.95$ & $>0.92$ & $>0.95$ & $>0.92$ & $>0.90$ \\
\hline NFI/TLI & $>0.97$ & $>0.95$ & $>0.92$ & $>0.95$ & $>0.90$ & $>0.80$ \\
\hline RMSEA & $<0.08$ & $<0.08$ & $<0.08$ & $<0.07$ & $<0.07$ & $<0.07$ \\
\hline SRMR & $<0.05$ & $<0.05$ & $<0.05$ & $<0.05$ & $<0.05$ & $<0.10$ \\
\hline
\end{tabular}

Source: Hooper, Coughlan and Mullen, 2008.

Fit indices obtained as a result of the final confirmatory factor analysis is analyzed. Goodness of fit values belonging to the scale developed by taking commonly used fit indices and acceptance ranges in Table 5 as reference are shown in Table 6.

Table 6: Goodness of fit values of airline lounge service quality scale

\begin{tabular}{|l|l|l|}
\hline Model Fit Indices & Results & Recommended Value \\
\hline $\boldsymbol{\chi 2} / \mathbf{d f}$ & 2.709 & $\leq 5$ \\
\hline GFI & 0.906 & $\geq 0.8$ \\
\hline AGFI & 0.866 & $\geq 0.8$ \\
\hline CFI & 0.929 & $\geq 0.9$ \\
\hline NFI & 0.893 & $\geq 0.9$ \\
\hline TLI & 0.910 & $\geq 0.9$ \\
\hline RMSEA & 0.076 & $\leq 0.08$ \\
\hline SRMR & 0.0640 & $\leq 0.10$ \\
\hline Source: Byrne, 2010.
\end{tabular}

When the values of goodness of fit are analyzed, it is seen that all of the values except for NFI value are between the recommended value range. The fact that NFI value is very close to the recommended value $(\geq 0,9)$ and also all of the other values are on the desired level shows that NFI value can be acceptable. Also, there are accepted studies in literature related to the fact that although NFI level is below the desired level, if the TLI level is above the recommended level, CFA 
result is supported (Hu and Bentler, 1999; Byrne, 2010). According to the analysis results, TLI result of the scale is above the reference value $(0,91)$.

After the confirmatory factor analysis, the hypotheses created in line with the purpose of the study must be tested. Table 7 shows the hypotheses created within the scope of the study.

Table 7: Hypotheses of the study

\begin{tabular}{|l|l|}
\hline Hypothesis 1 & $\begin{array}{l}\text { Image and accessibility of the lounges have a } \\
\text { positive significant effect on airline selection. }\end{array}$ \\
\hline Hypothesis 2 & $\begin{array}{l}\text { The atmosphere of the lounges has a positive } \\
\text { significant effect on airline selection. }\end{array}$ \\
\hline Hypothesis 3 & $\begin{array}{l}\text { Food \& beverage opportunities in lounges have } \\
\text { a positive significant effect on airline selection. }\end{array}$ \\
\hline Hypothesis 4 & $\begin{array}{l}\text { The opportunities belonging to the lounges } \\
\text { have a positive significant effect on airline } \\
\text { selection. }\end{array}$ \\
\hline
\end{tabular}

The hypotheses developed for the purpose of the study are tested with multivariate regression analysis. The main objective of using multiple regression analysis is the fact that it is the most suitable method used to test multiple independent variables and one dependent variable (Hair, Black, Babin and Anderson, 2009). There are some values that should be controlled before testing the hypotheses. Firstly, the independent variables and their correlations are evaluated. When the correlation values of the independent variables, which are put to hypothesis test, with the dependent variables and among themselves are analyzed, it is seen that their correlation coefficients are on the desired level $(<0,8)$. The second value that should be controlled after analyzing correlation coefficients table is VIF value. There are many different value range definition regarding VIF value in literature $(<2,5$; $<3 ;<5 ;<10)$. The purpose of controlling VIF values is to test if there is multicollinearity problem or not (Allison, 1999). When the VIF values of the independent variables used in hypothesis tests are analyzed, all values are seen to be below 2,5. Before testing hypothesis test results, Anova table should be analyzed lastly. When the significance value $(<, 008)$ on Anova table is analyzed, it is determined that at least one of the model's independent variables has an effect on the dependent variable $(<, 05)$. While the acquired significance value shows that at least one of the independent variables has an effect on the dependent variable, it doesn't indicate which independent variable is effective or its direction of effect. It is required to analyze the coefficients table in order to test the hypotheses and understand the effect's direction. Significance value should be controlled in the first place to test the hypotheses. If the significance value (sig) is lower than 0,05 , then unstandardized beta (B) value should be controlled. If beta value is positive, the effect is interpreted as positive and if beta value is negative, the effect interpreted as negative. The fact that significance value is greater than 0,05 means that independent variable doesn't have an effect on the dependent variable. Table 8 shows the test results of the hypothesis created in line with the purpose of the study, significance and beta values.

Table 8: Hypothesis test results

\begin{tabular}{|c|c|c|c|c|}
\hline No & Sig & Beta & & Result \\
\hline 离 & .003 & .332 & $\begin{array}{l}\text { Image and accessibility of } \\
\text { the lounges have a positive } \\
\text { significant effect on airline } \\
\text { selection. }\end{array}$ & Supported \\
\hline 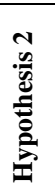 & .624 & .064 & $\begin{array}{l}\text { The atmosphere of the } \\
\text { lounges has a positive } \\
\text { significant effect on airline } \\
\text { selection. }\end{array}$ & Rejected \\
\hline 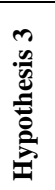 & .099 & -.188 & $\begin{array}{l}\text { Food \& beverage } \\
\text { opportunities in lounges } \\
\text { have a positive significant } \\
\text { effect on airline selection. }\end{array}$ & Rejected \\
\hline 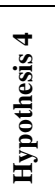 & .702 & 0.33 & $\begin{array}{l}\text { The opportunities } \\
\text { belonging to the lounges } \\
\text { have a positive significant } \\
\text { effect on airline selection. }\end{array}$ & Rejected \\
\hline
\end{tabular}

\section{Conclusions and Suggestions}

This study is conducted to identify the perceptions of the passengers using lounge services. In this part of the study, the conclusions obtained in line with the findings, academic and sectoral suggestions will be included.

\section{Conclusions}

The questionnaire prepared within the scope of the study is applied to the passengers who get lounge service at Izmir Adnan Menderes airport. When the participants are analyzed demographically, it is seen that males use lounge service predominantly. It is seen that participants mainly travel in economy class and with the purpose of holiday. It is also identified that passengers generally use the lounge service along with a close person.

Two different scales are used in the study. Service quality scale is created in order to identify the perceptions regarding the lounge services in general and another scale is developed for lounge 
services at İzmir Adnan Menderes airport domestic lines. The conclusions obtained in line with the findings of the study are listed as follows:

- When the answers to lounge services are analyzed, it is seen that passengers mostly give importance to the atmosphere dimension. This result reveals the necessity to care about interior design's being of good quality, environment's being cozy and comfortable, service's being provided in a kind and candid way and inner area's being wide and nice.

- The other important factor for the passengers regarding lounge services is food\&beverage. It is seen that passengers prefer to have different kinds of snacks and drinks, light meal choice and a quality menu at lounges.

- When the answers to airline lounge service quality scale are analyzed on the basis of items, it is concluded that passengers want the lounges to be at a favorable location. Also, the passengers' previous experiences regarding the lounge seems as an important factor. Another component that passengers using lounges think lounges should make available is the internet and computer infrastructure. Results of the study show that passengers don't pay too much attention to the availability of telecast, movie, telephone and printed publications (magazine, newspaper etc.). This result reveals that passengers meet all of these needs through one channel, which is the internet channel.

- It is identified that passengers attending the study care least about the availability of shower cabins at lounges. This result emanates from the biggest limitedness of the study. The facts that the study is conducted on the passengers using İzmir Adnan Menderes Airport domestic lines lounges and domestic lines passengers' lounge usage period and type differs compared to international line passengers set forth that the same study would acquire different findings if conducted on international lines passengers using lounges.

- The second scale used in the study was developed for the evaluation of İzmir Adnan Menderes Airport domestic lines lounges. When the answers of the participants are analyzed generally, it is seen that passengers perceive domestic lines services as being quite adequate.

- When the scale belonging to İzmir Adnan Menderes Airport domestic lines lounge services is analyzed on factor basis, it comes up that passengers are mostly satisfied with the staff competence dimension. It is determined that passengers are satisfied with lounge atmosphere, opportunities/activities and food\&beverage services respectively.

- The item that participants are satisfied with the highest rate is the statement of employees' being clean and well-dressed. This result shows that İzmir Adnan Menderes domestic lines management is highly careful about staff training and hygiene. It is determined that participants participated all of the statements in the descriptive analyses made for the scale at a quite high ratio. This result shows that passengers think İzmir Adnan Menderes domestic lines lounge service of being quite high quality.

- When the hypotheses developed in compatible with the purpose of the study are tested, it is ascertained that only image and availability variable, out of the dimensions belonging to airline lounge service quality, has a favorable and positive effect on airline selection. The other three dimensions of the scale did not have either positive or negative effect in airline selection.

\section{$\underline{\text { Suggestions }}$}

It is thought that sectoral contribution of the results obtained from the study predominates its academic contribution. Suggestions made in line with the results of the study are evaluated under two titles as academic and sectoral suggestions.

\section{- $\quad$ Theoretical suggestions}

One of the biggest limitedness of the study is that data was collected from the passengers using İzmir Adnan Menderes airport domestic lines lounge. Results that will be obtained from comparative studies to be made in lounges providing service at domestic and international lines of different national and international airports will bring different findings in the literature.

The biggest challenge in performing the study was acquiring dispensation for collecting data from passengers using lounge and data collection process. In the study, information is collected in certain time periods along with the dispensation gotten from the establishment. External factors such as some of the passengers' having had a rush because of the approaching departure time while answering the questions and some participants' rejecting to answering questions during resting time can affect the results of the study. It is suggested that the study should be conducted within the scope of a project and with supports from either public institutions or private organizations aimed at all airline lounges in Turkey and the results should be shared with 
public institutions and private sector (especially with aviation). In this way, healthier and flawless provision of lounge services will be enabled.

\section{- Practical suggestions}

The great majority of the results obtained from the study are sectoral outputs. The sectoral suggestions are made by disregarding the constraints of the study. Applying the study in different regions on wider sample groups will enable findings and results to be clearer.

It is understood that passengers highly pay attention to the atmosphere of lounges. Interior designs of lounges should be made in a quality way. Narrowness of lounges should be avoided and lounge area should be planned in a wide and spacious way.

The fact that passengers care about the quality and diversity of foods and beverages in lounges is another important result obtained by the study. Menu diversity of food\&beverage services in lounges should be provided and the adequateness of products and services should frequently be controlled. If necessary, outsourcing can be preferred in order to increase food\&beverage standards in lounges.

When the answers regarding airline lounge services and İzmir Adnan Menderes Airport domestic lines lounge services are analyzed in detail, it is seen that one of the services that passengers pay most attention to is the internet and computer infrastructure. With reference to this result, it can be said that computers in lounges should meet the requirements of the passengers, and also, internet infrastructure shouldn't lose power even on maximum connection status. It is important that managers organizing lounge services or staff to especially warn the internet supplied regarding such issues and if necessary, make a second plan for possible cut or breakdown conditions. Today, it should be taken into account that especially passengers travelling for business purpose can make important job meetings, correspondences, agreements etc. at lounges and it should be remembered that problems caused by internet or computers could cause big customer losses for related airline lounge and the airline.

Along with the effect of the internet, people can follow and manage many platforms through one channel and it can decrease the interest in the classic mediums. When the results of the study are analyzed carefully, it is determined that passengers pay great attention to internet and computer infrastructure but they do not care much about the availability of telecast and movies, telephone, and printed publications such as magazines and newspapers. Instead of classic telecommunications devices in airline lounges, important news of the day can be shown to the passengers visually by providing kiosks, which are more compatible with today's digital world. By means of contracts that can be made with technology companies, new telephone, tablet pc or other technologic product models of brands can be promoted in a corner of lounge and thus, cost of lounge area can be reduced.

Finally, airline companies are suggested to make necessary operations in order to increase the image and accessibility in lounges. The results obtained from the study show that image and accessibility has an effective role in airline selection. Lounges with a favorable location within the airport, effective promotion activities that will be made through internet, social media, printed and visual media will enable the increase of lounge image. Corporate membership should be acquired in different social media accounts (such as Google, Facebook, Instagram) for lounges. Moreover, passengers who get service and leave contently should be advised to relay the experiences in these medias. Thus, image and accessibility level of lounges will increase with the effect of social media.

\section{References}

Allison, P. D. (1999). Multiple regression: A primer. Pennsylvania: Pine Forge Press.

Archana, R., \& Subha, M. V. (2012), A study on service quality and passenger satisfaction on Indian airlines. International Journal of Multidisciplinary Research, 2 (2), 50 - 63.

Bakırtaş, H. (2010). AVM'lerde Mağaza içi atmosferin tüketim duyguları ve satın alma davranışı üzerindeki etkisi. Unpublished phd thesis, Sakarya University.

Byrne, B. M. (2010). Structural Equation Modeling with AMOS: Basic Concepts, Applications and Programming. (2. Baskı). New York: Routledge.

Fick, G. R., \& Ritchie, J. R. B. (1991). Measuring service quality in the travel and tourism industry. Journal of Travel Research, 30(2), 2 - 9. doi: 10.1177/004728759103000201

Hair, J. F., Black, W.C., Babin, B.J., \& Anderson, R.E. (2009). Multivariate Data Analysis. (7th Edition). Essex: Pearson.

Halis, M. (2010). Toplam kalite yönetiminin temel kavramları. In Ş. Demirkol \& M. Halis (Eds.), Turizm Işletmelerinde Toplam Kalite Yönetimi. İstanbul: Değişim Aktüel Yayınevi. 
Han, S., Ham, S. S., Yang, I., \& Baek, S. (2012). Passengers' perceptions of airline lounges: Importance of attributes that determine usage and service quality measurement. Tourism Management, 33, $1103 \quad$ - 1111. doi:10.1016/j.tourman.2011.11.023

Hooper, D., Coughlan, J., \& Mullen, M. (2008). Structural Equation Modelling: Guidelines for Determining Model Fit. The Electronic Journal of Business Research Methods, 6 (1), 53 - 60.

Hu, L. T., \& Bentler, P. M. (1999). Cutoff criteria for fit indexes in covariance structure analysis: Conventional criteria versus new alternatives. Structural Equation Modeling: A Multidisciplinary Journal, 6(1), 1 - 55. doi: 10.1080/10705519909540118

Kang, G-D., \& James, J. (2004). Service quality dimensions: An examination of Grönroos's service quality model. Managing Service Quality, 14(4), 266 - 277. doi: 10.1108/09604520410546806

Kline, P. (1994). An Easy Guide to Factor Analysis: New York: Routledge.

Kotler, P. (1997). Marketing management: Analysis, planning, implementation and control. New Jersey: Prentice Hall International.

Küçükaltan, G. (2007). Hizmet kalitesi kavramına genel bir yaklaşım ve hizmet kalitesinin önemi. In $\mathbf{S}$. Gümüşoğlu, İ. Pınar, P. Akan, \& A. Akbaba (Eds.), Hizmet kalitesi: Kavramlar, yaklaşımlar ve uygulamalar (pp. 57-71). Ankara: Detay.

Munusamy, J., Chelliah, S., \& Pandian, S. (2011) Customer satisfaction delivery in airline industry in Malaysia: A case of low cost carrier. Australian Journal of Basic and Applied Sciences, 5(11), 718 $-723$.

Okumuş, A., \& Asil, H. (2007). Hizmet kalitesi algilamasinin havayolu yolcularının genel memnuniyet düzeylerine olan etkisinin incelenmesi. Istanbul Üniversitesi Isletme Fakültesi İsletme Dergisi, 36(2), 7 - 29 .

Osborne, J. W., \& Fitzpatrick, D. C. (2012). Replication analysis in exploratory factor analysis: what it is and why it makes your analysis better. Practical Assessment, Research \& Evaluation, 17(15), 1-8. doi: 10.7275/h0bd-4d11

Özer, P. S., \& Özdemir, P. Ö. (2007). Hizmet kavramı, ekonomideki yeri tanımı ve özellikleri. In Ş. Gümüşoğlu, İ. Pınar, P. Akan, \& A. Akbaba (Eds.), Hizmet kalitesi kavramlar yaklaşımlar, uygulamalar. Ankara: Detay Yayıncılık.

Park, J. W., Robertson, R., \& Wu, C. L. (2005). Investigating the effects of airline service quality on airline image and passengers' future behavioral intentions: Finding from Australian
International air passengers. The Journal of Tourism Studies, 16(1), 1 - 11 .

Reyment, R., \& Jöreskog, K. G. (1996). Applied Factor Analysis in the Natural Sciences. New York: Cambridge.

Saha, G. C. \& Theingi, T. (2009). Service quality, satisfaction, and behavioural intentions: A study of low-cost airline carriers in Thailand. Managing Service Quality: An International Journal, 19(3), 350 - 372. doi: 10.1108/09604520910955348

Solomon, M., Surprenant, C., Czepiel, J., \& Gutman, E. (1985). A role theory perspective on dyadic interactions: The service encounter. Journal of Marketing, 49(1), 99-111. doi:10.2307/1251180

Suhr, D. D. (2006). Exploratory or confirmatory factor analysis?. Cary: SAS Institute.

Tütüncü, Ö. (2001). Yiyecek içecek işletmelerinde müssteri tatmininin ölçülmesi. Ankara: Turhan Kitabevi.

Uz, C. Y., \& Canarslan, N. Ö. (2019). Havayolu hizmet kalitesinin yolcu memnuniyeti üzerine etkisi. Turkish Studies, 14(4), 2905 - 2922. doi: 10.29228/TurkishStudies.23452

Yamak, O. (1998). Kalite odaklı yönetim. İstanbul: Panel Matbaacilık.

Yaşlıoğlu, M. M. (2017). Sosyal bilimlerde faktör analizi ve geçerlilik: Keşfedici ve doğrulayıcı faktör analizlerinin kullanılması. Istanbul University Journal of the School of Business, 46, $74-85$. 


\title{
INFO PAGE
}

The effect of airline lounge services on the selection of airline

\begin{abstract}
The services provided at lounges, designed in line with various needs with the purpose of enabling the passengers to make use of the waiting time at the airports, affect the selection of airlines. In this study, the effect of image and accessibility, atmosphere, food \& beverage and opportunities (activity) dimension belonging to lounge scale on the selection of airline is analyzed. The utmost limitedness of the study is conducting the questionnaires on passengers using izmir Adnan Menderes airport domestic flights lounge. The questionnaires and comparative analyses to be conducted at different airports will add another dimension to the study. "Image and accessibility of the lounges have a positive significant effect on airline selection" is the only accepted hypotheses of the study. The most important result obtained from the study is that image and accessibility dimension among the lounge services has a significant and positive effect in the selection of the airline. In accordance with the results of the study, it is suggested to airlines to position the lounges within the airport to a place that passengers can easily reach, share the feedbacks of the passengers using the lounges via social media channels, promote the passengers to recommend the lounges and finally follow correct marketing exercises and sales techniques.
\end{abstract}

Keywords: Lounges, Service quality, Lounges and service quality

\section{Authors}

Samet Can Curkan: Methodology, Validation, Formal analysis, Data Curation, Writing - Original Draft,

Author statement: Author(s) declare(s) that All procedures performed in studies involving human participants were in accordance with the ethical standards of the institutional and/or national research committee and with the 1964 Helsinki declaration and its later amendments or comparable ethical standards.

This paper does not required ethics committee report Justification: The data were collected in 2019, ethics committee approval is not required. 